\title{
CREATIVELY GIFTED STUDENTS AND THEIR PEDAGOGICAL SUPPORT
}

\section{[TVORIVO NADANI ZIACI A ICH PEDAGOGICKA PODPORA]}

\author{
Dusan Fabik
}

doi: 10.18355/PG.2018.7.2.7

\begin{abstract}
The publication focuses on the specific group of children with creative giftedness. In the introduction, there is defined the concept of creativity and creative giftedness, which is characterized as the potential for achievement of superior creative performances. Following are possible ways (psychological and pedagogical ones) of identification of these children. The work approaches the dominant and typical features of gifted children such as nonconformity or a wide range of interests. Most of the work is focused on the support of children from the point of view of teachers. Emphasis is placed on the educational environment and the means, curiosity and discussion, the micromoments and the feedback.
\end{abstract}

\section{Key words}

creative giftedness, identification of giftedness, pedagogical support

\section{Anotácia}

Publikácia sa zameriava na špecifických žiakov s tvorivým nadaním. V úvode vymedzuje pojem tvorivost' a tvorivé nadanie, ktoré charakterizuje ako potenciál pre dosahovanie nadpriemerných tvorivých výkonov. Nasledujú možné spôsoby identifikácie týchto žiakov, a to z pohl'adu psychologického ako aj pedagogického. Práca približuje aj dominantné a typické vlastnosti tvorivo nadaných žiakov ako je nonkonformita alebo široké spektrum záujmov. Najväčšia čast' práce je zameraná na možnosti podpory žiakov z pohl'adu pedagógov. Dôraz sa kladie na edukačné prostredie a prostriedky, zvedavost' a diskutovanie, mikromomenty a spätnú väzbu.

\section{Kl’účové slová}

tvorivé nadanie, identifikácia nadania, pedagogická podpora

\section{Tvorivost'}

Výskumníci v oblasti tvorivosti sa obyčajne zhodujú, že tvorivost' zahŕňa dva základné komponenty: inovatívnost' a vhodnost' (Kaufman et al., 2018). To znamená, že nápad, myšlienka či správanie je považované za tvorivé ak je jedinečné alebo ojedinelé $s$ nízkou frekvenciou výskytu a zároveň je primerané podstate riešeného problému. D. Simonton (2012) vyjadril tento vzt’ah rovnicou, kde sa tvorivost' rovná súčinu inovatívnosti a vhodnosti. Súčin použil $\mathrm{v}$ tejto rovnici $\mathrm{z}$ dôvodu, aby zdôraznil význam každého $\mathrm{z}$ dvoch činitel'ov. Jeden faktor bez druhého totiž nemá význam. Preto, ak je hodnota originality alebo vhodnosti nula, aj celkový tvorivý výkon bude nulový. R. 
Beghetto a J. Kaufman (2014) neskôr pridali do rovnice aj sociokulturálny kontext, čo znamená, že tvorivý výkon je nutné hodnotit' v kontexte prostredia. Napríklad, určitá myšlienka alebo prejav žiaka na základnej škole môže byt' ohodnotený ako neobyčajný, a teda tvorivý, ale v kontexte strednej prípadne vysokej školy školy sa už nemusí považovat' tvorivý.

Originalita a vhodnost' nie sú jediné možné faktory tvorivosti. Kognitívny psychológ M. Runco (2005) napríklad dopĺn̆a, že významným znakom tvorivosti je aj určitý takt alebo diskrétnost', ktorú definuje ako rozhodovanie sa, kedy je vhodné a užitočné byt' originálny a kedy to nie je vhodné resp. prínosné. Vysvetl'uje, že bez tohto taktu žije jedinec vo vlastnom fantazijnom svete a má bližšie k psychotikovi než sociálne užitočnej osobe. Príbuzným pojmom je metakognícia tvorivosti (creative metacognition), čo znamená uvedomovanie si svojich silných a slabých stránok tvorivého konania a vedomie kedy, kde ako a prečo byt’ tvorivý (Kaufman et al., 2016). Táto stránka pomáha rovnako zasadit' tvorivé správanie do určitého rámca, ktoré sa prejavuje v sociálne užitočnom správaní.

V kontexte daných informácií môžeme vymedzit' tvorivost' $\mathrm{v}$ súlade E. Szobiovou (2016, s. 24), ktorá ju definuje ako prejav systému osobnostných charakteristík, schopností a motivačných tendencií človeka $\mathrm{v}$ sociálnom kontexte, ktorý je nový, nezvyčajný, akceptabilný a objavný pre subjekt, referenčnú skupinu alebo spoločnost'.

\section{Tvorivé nadanie}

Tvorivé nadanie a tvorivo nadaní žiaci zdiel'ajú niektoré charakteristiky obdobné intelektovému nadaniu. Platí totiž, že pre vysoký tvorivý výkon je potrebná aj nadpriemerná inteligencia (Jauk et al., 2013). Vel'ká čast' edukačných programov pre intelektovo nadaných aj podporuje a kladie si za ciel' rozvoj tvorivosti, rovnako aj mnohé modely intelektového nadania zahŕn̆ajú tvorivost' ako jeden z komponentov. Aj výskumne opakovane zistilo, že intelektovo nadaní žiaci dosahujú obyčajne vyššiu mieru tvorivosti (Szobiová - Boleková, 2012; Szobiová - Šuplatová, 2006). Dokonca môžeme nájst' medzi intelektovo nadanými žiakmi a tvorivo nadanými žiakmi aj podobné osobnostné vlastnosti. Obyčajne sa obidve skupiny vyznačujú väčšou otvorenost'ou voči novým zážitkom, kritickým myslením, zvedavost'ou, intenzívnejším emočným prežívaním a menej obvyklými myšlienkovými procesmi.

Tvorivé nadanie je však v niektorých oblastiach až v kontraste s intelektovým nadaním (napr. Zenasni et al., 2016). Intelektovo nadaní žiaci majú vysoko nadpriemernú všeobecnú intelektovú spôsobilost' (Fábik, 2017), ktorá sa prejavujú vo verbálnych či matematických zručnostiach a majú predpoklad výborne prospievat' v bežných školských úlohách. Ich nadanie sa identifikuje pomocou štandardných intelektových testov. Naopak, tvorivý výkon sa zvykne v tradičných testoch odrážat' len v minimálnej miere. Toto nadanie je t’ažko meratel'né a v podstate nehmatatel'né. Na tvorivom nadaní sa podiel'ajú aj osobnostné, motivačné a emočné faktory. Ak vychádzame z bežného intelektového nadania, ktoré sa dá vymedzit' ako súčinnost' podnetného prostredia a genetickej dispozície vytvárajúce potenciál pre dosahovanie nadpriemerných kognitívnych výkonov (Fábik, 2018), potom tvorivé nadanie 
môžeme považovat' zase za potenciál pre dosahovania vysoko nadpriemerných tvorivých výkonov. Môžeme preto povedat', že tvorivo nadaný žiak vytvára rovnako ako matematicky alebo verbálne nadaný žiak, špecifickú kategóriu nadaných žiakov.

Napriek frekvencii využívania konštruktu tvorivosti sa však domnievame, že existuje rozkol medzi tým, ako bežné školy alebo špeciálne edukačné programy pracujú s tvorivými žiakmi a aké sú samotné potreby týchto žiakov. Ako dôvod prehliadania tejto diskrepancie vnímame fakt, že tvorivost' bola zahrnutá do všeobecných koncepcií inteligencie a intelektového nadania a dlhé obdobie sa o nej neuvažovalo ako o samostatnom konštrukte relatívne nezávislom na inteligencii. Predpokladalo sa, že pokial' rozvíjame vedomosti, znalosti či logické uvažovanie, rozvíjame zároveň aj tvorivost'.

Môžeme povedat', že identifikácia tvorivo nadaných žiakov je ukotvená aj na Slovensku. V rámci Metodických pokynov na zarad'ovanie detí do špeciálnych výchovno-vzdelávacích programov pre intelektovo nadaných žiakov (2008) v čl. 3 v bode 4 jestvuje bod b, ktorý považuje za nadaného žiaka toho žiaka, ktorého úroveň tvorivosti spadá do pásma horných $2 \%$ populačného ročníka, pričom jeho reprodukčné intelektové schopnosti dosahujú aspoň úroveň horných 10 \% populačného ročníka (IQ nad 120). Hoci sa $\mathrm{v}$ dokumente priamo neuvádza, že sa jedná o tvorivo nadaného jedinca, tieto diagnostické kritéria môžeme považovat' za vhodné pre jeho identifikáciu. Ako prínosné stanovisko hodnotíme, že v prípade, že daný žiak disponuje vysoko nadpriemernou tvorivost'ou nemusí dosahovat' obligátnu hranicu 130 bodov pre priznanie nadania, ale je hranica posunutá nižšie na 120 bodov. Oprávnenost' tohto aspektu potvrdzujú súčasné štúdie, ktoré preukazujú, že vel'mi vysoká tvorivost' nebýva spätá s vel'mi vysokou inteligenciou (napr. Fernández et al., 2017; Guignard et al., 2016).

\section{Charakteristika tvorivo nadaných žiakov}

Tvorivo nadaní žiaci pracujú prevažne samostatne a často prichádzajú $\mathrm{s}$ bizarnými riešenia problémov. Títo žiaci nebývajú motivovaní absolvovaním daného ročníka alebo školy. Dá sa povedat', že väčšina externých motívov, ktoré sa uplatňujú pri iných det'och, neplatia pre tvorivo nadané. Tvorivo nadaní žiaci sa vyznačujú nezávislým myslením a majú imaginatívnu (tvorivú) inteligenciu, zatial' čo intelektovo nadaní sa vyznačujú skôr schopnost'ou riadit' informácie a výbornými akademickými spôsobilost'ami. Ked' bežný nadaný žiak hl'adá správnu odpoved' na otázku, obyčajne si vyberie nejakú ponúknutú možnost'. Ked' však rieši úlohu tvorivo nadaný žiak, l'ahko sa mu stane, že z jeho pohl'adu ideálna možnost' nie je medzi vol'bami. Podstatným znakom tvorivo nadaného jedinca je jeho nonkonformita, ktorá sa prejavuje u jedinca vlastným spôsobom konania. Robí veci podl'a seba, nestará sa, aby sa prispôsobil tomu, čo robia ostatní žiaci. Rovnako neprijíma vyhlásenia autority bez konštruktívneho a kritického zhodnotenia. Ich nonkonformitu možno badat' aj napríklad v zmysle pre humor, kedy môžu vidiet' komické situácie aj za okolností, ktoré 
nemusia byt' zábavné pre ostatných. Niekedy to čo považujú za zábavné, sa môže javit' v očiach ostatných až ako nevhodné alebo nesprávne.

Žiaci sa vyznačujú aj špecifickou vynaliezavost'ou a inovatívnost'ou pri riešení problémov, ku ktorým pristupujú vo vel'kej miere najmä intuitívne. Sú schopní porozumiet' a pochopit' existujúcim procesom a javom a v rámci nich vykonat' svoje vlastné zlepšenia. Často sa prejavujú ako zvedaví jedinci, ktorí kladú množstvo otázok v rôznych súvislostiach. Typické je široké spektrum záujmov v mnohých, aj nesúviciacich oblastiach. Žiak môže mat' zároveň záujem o fotografovanie, šport alebo literatúru. K bežným charakteristikám môžeme priradit' aj schopnost' improvizácie, denné snenie, ochota riskovat' a skúšat' nové veci (dobrodružnost'), radost' z odlišnosti a samozrejme predstavivost', teda schopnost' nájst' nové spôsoby využitia veci, obzvlášt' bežných objektov (napr. použitie škatule alebo vankúšov ako pevnosti, hradu či jaskyne). Vlastnosti, ktoré sa naopak nespájajú za bežných okolností s tvorivo nadanými žiakmi vymedzili E. Westby a V. Dawson (2010) a radia medzi ne: toleranciu, spol'ahlivost', zodpovednost', pochopenie, praktickost', logickost', stálost' alebo rozumnost'.

Pre identifikáciu tvorivo nadaných žiakov v škole môže byt' pre učitel'ov užitočný zoznam ich prejavov správania. V tomto prípade má najväčší význam komparácia troch kategórii študentov od B. Kingorovej (2004): ciel'avedomého (úspešného) žiaka, (intelektovo) nadaného žiaka a tvorivo nadaného žiaka. Repertoár správania tvorivo nadaného žiaka poskytuje relatívne presný obraz o týchto žiakov, a čo je hlavné, umožňuje ich odlíšenie od bežných nadaných žiakov.

Tabul'ka 1 Porovnanie prejavov správania ciel'avedomého žiaka, nadaného žiaka a tvorivého myslitel'a

\begin{tabular}{|c|c|c|}
\hline Ciel'avedomý žiak & Nadaný žiak & Tvorivo nadaný žiak \\
\hline Pamätá si odpovede. & $\begin{array}{c}\text { Dáva nepredvídané } \\
\text { otázky. }\end{array}$ & Vníma výnimky. \\
\hline Prejavuje záujem. & Je zvedavý. & Dumá. \\
\hline Je pozorný. & Mysel' zapája selektívne. & $\begin{array}{c}\text { Fantazíruje; môže sa } \\
\text { zdat', že je } \\
\text { myšlienkami mimo. }\end{array}$ \\
\hline Má vyspelé nápady. & $\begin{array}{c}\text { Tvorí komplexné, } \\
\text { abstraktné nápady. }\end{array}$ & $\begin{array}{c}\text { Prekypuje nápadmi, } \\
\text { ktorých mnohé nikdy } \\
\text { nebudú rozvinuté. }\end{array}$ \\
\hline $\begin{array}{c}\text { Na úspechu tvrdo } \\
\text { pracuje. }\end{array}$ & $\begin{array}{c}\text { Má znalosti bez toho, } \\
\text { aby tvrdo pracoval. }\end{array}$ & $\begin{array}{c}\text { Hrá sa s názormi a } \\
\text { konceptmi. }\end{array}$ \\
\hline $\begin{array}{c}\text { Na otázky odpovedá } \\
\text { podrobne. }\end{array}$ & $\begin{array}{c}\text { Uvažuje do hĺbky a vo } \\
\text { viacerých perspektívach }\end{array}$ & $\begin{array}{c}\text { Predstavuje nové } \\
\text { možnosti. }\end{array}$ \\
\hline Je najlepší v skupine. & $\begin{array}{c}\text { Presahuje úroveň } \\
\text { skupiny. }\end{array}$ & $\begin{array}{c}\text { Tvorí svoju vlastnú } \\
\text { skupinu. }\end{array}$ \\
\hline $\begin{array}{c}\text { Odpovedá so záujmom } \\
\text { a vlastným názorom. }\end{array}$ & $\begin{array}{c}\text { Vyjadruje pocity } \\
\text { a názory z viacerých } \\
\text { perspektív. }\end{array}$ & $\begin{array}{c}\text { Zdiel'a bizarné, občas } \\
\text { konfliktné názory. }\end{array}$ \\
\hline L'ahko sa učí. & Už vie. & Pýta sa: Čo ak... \\
\hline
\end{tabular}

Slavonic Pedagogical Studies Journal, ISSN 1339-8660, eISSN 1339-9055, Volume 7 Issue 2, September 2018 


\begin{tabular}{|c|c|c|}
\hline $\begin{array}{l}\text { Aby niečo zdokonalil, } \\
\text { musí si to zopakovat' } 6 \\
\text { až } 8 \text { krát. }\end{array}$ & $\begin{array}{c}\text { Potrebuje } 1 \text { až } 3 \\
\text { opakovania na } \\
\text { zdokonalenie. }\end{array}$ & $\begin{array}{l}\text { Spochybňuje potrebu } \\
\text { dokonalosti. }\end{array}$ \\
\hline $\begin{array}{l}\text { Chápe na vysokej } \\
\text { úrovni. }\end{array}$ & $\begin{array}{l}\text { Rozumie hlbokým } \\
\text { a komplexným } \\
\text { myšlienkam. }\end{array}$ & $\begin{array}{l}\text { Prekypuje nápadmi, } \\
\text { z ktorých mnohé nikdy } \\
\text { nebudú rozvinuté. }\end{array}$ \\
\hline $\begin{array}{l}\text { Cíti sa dobre medzi } \\
\text { vrstovníkmi. }\end{array}$ & $\begin{array}{l}\text { Dáva prednost' } \\
\text { intelektuálnym } \\
\text { rovesníkom. }\end{array}$ & $\begin{array}{c}\text { Dáva prednost' } \\
\text { kreatívnym } \\
\text { rovesníkom, často však } \\
\text { pracuje sám. }\end{array}$ \\
\hline $\begin{array}{l}\text { Chápe komplexný, } \\
\text { abstraktný humor. }\end{array}$ & $\begin{array}{l}\text { Vytvára komplexný, } \\
\text { abstraktný humor. }\end{array}$ & $\begin{array}{l}\text { Užíva si výstredný, } \\
\text { nekonvenčný humor. }\end{array}$ \\
\hline Zachytí pointu. & Zahŕňa a spája koncepty. & $\begin{array}{l}\text { Riešenia vidí odrazu a } \\
\text { nečakane: Aha! }\end{array}$ \\
\hline Plní úlohy včas. & $\begin{array}{l}\text { Iniciuje projekty } \\
\text { a rozšírenia projektov. }\end{array}$ & $\begin{array}{l}\text { Iniciuje viac projektov, } \\
\text { ako je možné kedy } \\
\text { dokončit'. }\end{array}$ \\
\hline Je vnímavý. & Je intenzívny. & $\begin{array}{l}\text { Je nezávislý a } \\
\text { nekonvenčný. }\end{array}$ \\
\hline $\begin{array}{l}\text { Je presný a } \\
\text { stopercentný. }\end{array}$ & $\begin{array}{c}\text { Je originálny } \\
\text { a nepretržite napreduje. }\end{array}$ & $\begin{array}{l}\text { Je originálny } \\
\text { a nepretržite } \\
\text { napreduje. }\end{array}$ \\
\hline $\begin{array}{l}\text { V škole je často vel'mi } \\
\text { rád. }\end{array}$ & $\begin{array}{l}\text { Teší ho učenie, ktoré si } \\
\text { sám riadi. }\end{array}$ & Rád tvorí. \\
\hline Absorbuje informácie. & Pracuje s informáciami. & Improvizuje. \\
\hline $\begin{array}{l}\text { Je technik s odbornými } \\
\text { znalost'ami v určitej } \\
\text { oblasti. }\end{array}$ & $\begin{array}{l}\text { Je expert, ktorý koná } \\
\text { mimo zadanú oblast'. }\end{array}$ & $\begin{array}{l}\text { Je vynálezca a tvorca } \\
\text { nápadov. }\end{array}$ \\
\hline $\begin{array}{l}\text { Dobre sa učí } \\
\text { naspamät'. }\end{array}$ & $\begin{array}{l}\text { Háda a správne } \\
\text { vyvodzuje. }\end{array}$ & $\begin{array}{c}\text { Tvorí a dobre pracuje } \\
\text { pri vzájomnej diskusii } \\
\text { pri hl'adaní riešení. }\end{array}$ \\
\hline $\begin{array}{c}\text { Je vel'mi pozorný a v } \\
\text { strehu. }\end{array}$ & $\begin{array}{c}\text { Predpokladá a nachádza } \\
\text { súvislosti } \\
\text { v pozorovaniach. }\end{array}$ & Je intuitívny. \\
\hline $\begin{array}{l}\text { Je spokojný s vlastným } \\
\text { vzdelávaním. }\end{array}$ & Je sebakritický. & $\begin{array}{l}\text { Možnosti sú pre neho } \\
\text { nekonečné. }\end{array}$ \\
\hline Dostáva jednotky. & $\begin{array}{c}\text { Známky preňho nemusia } \\
\text { byt' motiváciou. }\end{array}$ & $\begin{array}{l}\text { Známky preňho } \\
\text { nemusia byt' } \\
\text { motiváciou. }\end{array}$ \\
\hline Je schopný. & Je intelektuál. & Je svojrázny. \\
\hline
\end{tabular}

Komplikácia, na ktorú treba upozornit' je, že tvorivo nadané diet’a môže vykazovat' všetky alebo len niektoré z vyššie uvedených charakteristík - deti sa od seba do vel'kej miery líšia. Chybné interpretácie môže taktiež spôsobit' nadmerná aktivita žiakov, nekonvenčnost' a množstvo netypických otázok. Svojím špecifickým obrazom v kombinácii s vysoko tvorivou osobnostou môže žiak pôsobit’ nepozorne a vyvolávat' predstavu o diagnóze ADHD. 


\section{Pedagogická podpora tvorivo nadaných žiakov}

Tvorivá osoba sa teda vyznačuje väčšou otvorenost’ou (Kaspi-Baruch, 2017), nonkonformitou (Günçer \& Oral, 1993) či optimizmom (Icekson et al., 2014). Každá z týchto čŕt a mnohých d’alších sa spolupodiel'a na tvorivom správaní, ktoré svojou povahou vedie k netradičným, t’ažšie prijímaným a niekedy aj odmietaným nápadom. Nie je výnimkou ak je tvorivo nadaný žiak neprávom hodnotení ako žiak $\mathrm{s}$ menším potenciálom. Učitelia preto musia byt' dostatočne informovaní a vzdelávaní $\mathrm{v}$ problematike tvorivo nadaných žiakov. Aj výskumy (napr. Andiliou \& Murphy, 2010) zistili, že presvedčenia a znalosti učitel'ov $\mathrm{v}$ oblasti tvorivosti sú často $\mathrm{v}$ nesúlade $\mathrm{s}$ poznatkami vedeckých teórií. Medzi bežné chybné presvedčenia patrí napríklad myšlienka, že tvorivost' je len geneticky podmienená schopnost', súvisí primárne s umením, prípadne, že tvorivost' vyžaduje len faktor inovatívnosti resp. originality (druhý faktor, ktorý učitelia neevidujú je vhodnost'). Navyše sa učitelia neraz stretávajú aj s mnohými objektívnymi bariérami rozvoja tvorivosti: nedostatok času, preplnené učebné osnovy či nutnost' a tlak na neustále známkovanie. Výskum (Bereczki \& Kárpáti, 2018), ktorý je syntézou 53 štúdii zároveň poukázal na nesúlad medzi pozitívnymi presvedčeniami učitel'ov $\mathrm{k}$ tvorivosti a praktickými postupmi na vyučovaní. To znamená, že hoci učitelia môžu mat' adekvátne presvedčenia o tvorivosti, zriedka sa "pretavujú" do konkrétnych praktických činností v edukačnom procese. Učitelia teda nutne potrebujú podporu v rozširovaní vedomostí ohladom prejavov tvorivo nadaných žiakov a pedagogických postupov pri ich rozvíjaní. $\mathrm{Na}$ druhej strane sa ukazuje, že učitelia majú aj mnohé presvedčenia, ktoré môžu výrazne podporovat' tvorivost' v triede. Mnohí napríklad veria, že tvorivost' je možné rozvíjat' u každého žiaka v rámci viacerých vyučovacích predmetov. Taktiež platí, že niektoré vlastnosti učitel'a (tvorivost' samotného učitel'a, skúsenosti) majú vplyv na povedomie a presvedčenia učitel'ov o tvorivosti (Mullet et al., 2016) a pravdepodobne aj vedú $\mathrm{k}$ tvorivejším postupom na vyučovaní. Nasleduje niekol'ko poznatkov vyplývajúcich z praktických skúseností aj aktuálnych výskumných štúdií, ktoré môžu pomôct' pedagógom podporovat' tvorivo nadaných žiakov a pomôct' im rozvíjat' ich jedinečné nadanie:

\section{Využivat' všetky edukačné prostredia a prostriedky}

D. Davies et al. (2013) identifikovali osem oblastí, ktoré môžu v edukačnom prostredí stimulovat' žiakovu tvorivost'. Pokial' ide o fyzické prostredie, odporúčajú autori najmä využívanie priestoru v triede alebo rozličné učebne. Ďalej odporúčajú dbat' na široký rozsah dostupných zdrojov a materiálov. Tretí a štvrtý faktor sa týka výučby vonku (napr. na školskom dvore) a úloh/činností, ktoré by mali byt' nové, realistické a vzrušujúce, a dovolujúce žiakovi preberat' zodpovednost' za svoje vzdelávanie. Ďalší podstatný faktor, ktorý autori pripomínajú je hra vo vyučovaní a dostatok času pre žiakov pri riešení úloh. Aspekt, ktorý uvádza štúdia obsiahlejšie sú vzt’ahy žiakov s učitel'mi, kedy vzt'ahy založené na vzájomnej dôvere a rešpekte tvoria základ 
psychosociálneho prostredia podporujúce tvorivost'. Posledný atribút pre podporu tvorivosti odporúča využívanie mimoškolských prostredí ako sú galérie či múzeá.

\section{Klást' dôraz na zvedavost' a diskutovanie}

Tvorivý potenciál a výkon nie je stabilnou súčastou osoby, ale neustále sa vyvíja prostredníctvom rodinného a školského prostredia. To znamená, že je nutné vytvárat' také prostredie, ktoré vyzýva a podporuje tvorivé myslenie. Vo všeobecnosti môžeme podporit' vrodený potenciál pre tvorivé správanie tým, že žiaka vystavíme faktorom, ktoré poskytujú inšpiráciu a umocňujú zvedavost'. V praxi to znamená podporovat' chut' $\mathrm{k}$ čítaniu, poznávaniu a predstavovaniu, čím žiak spozná mnohé nové perspektívy. Takisto môže byt' prínosný čas, kedy môže diet’a hádat', čosi vytvárat' alebo diskutovat'. Najmä pri diskusiách však musí byt' učitel' nanajvýš obzretný. Typický scenár pri diskusiách $\mathrm{v}$ triede totiž často vyzerá tak, že učitel' okamžite hodnotí správnost' odpovede študenta. Namiesto okamžitého vyhodnocovania správnosti neočakávaného nápadu študenta by sa učitel' mal snažit' pristupovat' $\mathrm{k}$ týmto nápadom so záujmom a ochotou ich preskúmat' (napr. „Vieš mi povedat' príklad toho, aká je Tvoja konkrétna predstava alebo čo si pod tým predstavuješ?"). Tento prístup si vyžaduje, aby učitel' posmel'oval študentov $\mathrm{k}$ vyjadrovaniu ich vlastných názorov a myšlienok, a aby si pozorne vypočul ich nápady.

\section{Mikromomenty}

Na prvý pohlad nenápadný, ale podstatný faktor na vyučovaní, ktorý umožňuje podporit' tvorivost' a rôznorodost' myslenia sú tzv. mikromomenty (Beghetto, 2013). Jedná sa o krátke, prekvapivé momenty tvorivého potenciálu vznikajúce v každodennej vyučovacej rutine, kedy študent vysloví a zdiel'a nejakú neočakávanú myšlienku alebo neobyčajný námet na diskusiu. $\mathrm{V}$ takom prípade by mal učitel' podporit', ocenit' a $\mathrm{v}$ ideálnom prípade aj rozvinút' podobné tvorivé nápady. Ak učitel' prehliada netradičné návrhy alebo ich dokonca odmieta, trestá a bagatelizuje, vedie žiakov ku konformného spôsobu myslenia, kedy sa žiaci len snažia odhadnút' čo chce učitel' počut' a ako to chce počut'. Podobne môže žiak, ktorý má tendenciu prejavovat' odlišné a netradičné názory, svoje pohnútky potlačit' pokial' napríklad učitel' povie, že "úloha je na čas", a že "iba správne odpovede budú odmenené". Ak je v triede dominancia takýchto pokynov a prevažuje kritické a normatívne hodnotenie, žiaci rýchlo pochopia (prevažne na nevedomej úrovni), že tvorivost' nie je vyžadovaná príp. je až negatívne ohodnotená. R. Beghetto (2014) nazýva tento proces mortifikácia tvorivosti (creative mortification), ktorú chápe ako stratu ochoty a snahy zdiel'at' akékol'vek tvorivé nápady a myšlienky. Vyplýva najmä $\mathrm{z}$ opakovaných negatívnych skúseností, ktoré sú spojené $\mathrm{s}$ hanbou, nepochopením a odmietaním tvorivých nápadov zo strany autority, $\mathrm{v}$ tomto prípade od učitel'a. 
Pozitívna spätná väzba naznačuje, že si učitel' uvedomuje pokrok žiakov a je schopný poskytovat' študentom vedenie aj $\mathrm{v}$ nasledujúcich osobných a edukačných ciel'och. Spätná väzba by sa mala zamerat' na motiváciu a angažovanost' študenta $\mathrm{v}$ danej téme, nie na známku. Zredukovanie spätnej väzby na známku podporuje vonkajšiu motiváciu a bráni rozvíjaniu tvorivého myslenia. Ideálny je konkrétny a špecifický komentár, ktorý zhodnotí pôsobenie žiaka $\mathrm{v}$ triede, ale zároveň zachováva príp. podporí vnútornú motiváciu a tvorivé myslenie daného žiaka. Zároveň platí, že spätná väzba by nemala byt' ani príliš tvrdá, ani príliš slabá, jemná. Príliš tvrdá a nešetrná spätná väzba môže dusit' tvorivé myslenie (a prípadne až spôsobit' mortifikáciu tvorivosti). Naopak, nezaslúžená chvála alebo jemná spätná väzba pôsobí pre žiakov dehonestujúco. Žiaci môžu začat' mat' pochybnosti o svojich schopnostiach a domnievat' sa vzhl'adom na neprimeranú podporu, že nie sú dost' dobrí, aby boli hodnotení objektívne.

\section{Záver}

Tvorivo nadaných žiakov musíme považovat' za odlišnú kategóriu od bežných intelektovo nadaných žiakov. Je nevyhnutné im venovat' rovnakú pozornost' pri identifikácii ich potenciálu a dávat' im príležitost' študovat' $\mathrm{v}$ špeciálnych edukačných programoch pre nadané deti. Domnievame sa, že práve $\mathrm{v}$ najbližších rokoch bude neustále narastat na význame tvorivost' pri rastúcom pokroku spoločnosti a úlohou týchto l'udí bude hl'adat' nové riešenia a postupy ako sa vysporiadat's narastajúcimi globálnymi problémami. Ak im naša spoločnost' pomôže teraz, oni môžu spoločnosti pomôct' neskôr.

\section{Bibliographic references}

ANDILIOU, A. - MURPHY, K. 2010. Examining variations among researchers' and teachers' conceptualizations of creativity: A review and synthesis of contemporary research Educational Research Review, 5(3), p. 201-219.

BEGHETTO, R.A. 2014. Creative mortification: Aninitialexplortion. Psychology of Aesthetics, Creativity, and theArts, 8(3), p. 266-276.

BEGHETTO, R.A. 2013. Nurturing creativity in the micromoments of the classroom. In K.H.Kim (Eds.), Creatively gifted students are not like other gifted students: Research, theory, and practice, p. 3-15.

BEGHETTO, R. - KAUFMAN, J. 2014. Classroom contexts for creativity High Ability Studies, 25, p. 53-69.

BERECZKI, E. - KARPATI. 2018. Teachers' beliefs about creativity and its nurture: A systematic review of the recent research literature. Educational Research Review, 23, p. 25-56.

DAVIES, D. - JINDAL-SNAPE, D. - COLLIER, C. - DIGBY, R. - HAY, P. - HOWE, A. 2013. Creative learning environments in education-a systematic literature review Thinking Skills and Creativity, 8, p. 80-91.

FABIK, D. 2018. Identifikacia a podpora intelektovo nadanych ziakov s poruchami ucenia. In PEDAGOGIKA.SK, roc. 9, č. 1, s. 18-27. 
FABIK, D. 2017. Matematicky nadany ziak. Bratislava: Vydavatelstvo UK. ISBN 978-80-223-4226-1.

FERNANDEZ, E. - GARCIA, T. - ARIAS-GUNDIN, O. - VASQUEZ, A. RODRIGUEZ, C. 2017. Identifying Gifted Childre: Congruence among Different IQ Measures. Frontiers in Psychology, 8.

GUIGNARD, J. H. - KERMARREC, S. - TORDJMAN S. 2016. Relationships between intelligence and creativity in gifted and non-gifted children. Learn. Individ. Differ. 52 209-215

GUNCER, B. - ORAL, G. 1993. Relationship between creativity and nonconformity to school discipline as perceived by teachers of Turkish elementary school children, by controlling for their grade and sex. https:/www.researchgate.net/publication/232605494

Relationship_between_creativity_and_nonconformity_to_school_discipline as_perceived_by_teachers_of_Turkish_elementary_school_children_by_cont rolling_for_their_grade_and_sex

ICEKSON, T. - ROSKES, M. - MORAN, S. 2014. Effects of optimism on creativity under approach and avoidance motivation. Frontiers in Human Neuroscience, 8. https://www.ncbi.nlm.nih.gov/pmc/articles/PMC3937876/ JAUK, E. - BENEDEK, M. - DUNST, B. - NEUBAUER, A. 2013. The relationship between intelligence and creativity: New support for the threshold hypothesis by means of empirical breakpoint detection. Intelligence, 41(4), p. 212-221.

KASPI-BARUCH, O. 2017. Big Five Personality and Creativity: The 312 Moderating Effect of Motivational Goal Orientation. http://onlinelibrary.wiley.com/doi/10.1002/jocb.183/ full\#references

KAUFMAN, J. - LURIA, S. - BEGHETTO, R. 2018. Creativity. In S.I.Pfeiffer (Eds.), APA Handbook of Giftedness and Talent. Washington, DC, US: American Psychological Association. ISBN 978-1-4338-2696-2

KAUFMAN, J. - BEGHETTO, R. - WATSON, C. 2016. Creative metacognition and self-ratings of creative performance: A 4-C perspective. Learning and Individual Differences, 51, p. 394-399.

KINGORE, B. 2004. High Achiever, Gifted Learner, Creative Learner. http://www.bertiekingore.com/high-gt-create.htm

METODICKE POKYNY NA ZARADOVANIE DETI DO SPECIALNYCH VYCHOVNO-VZDELAVACICH PROGRAMOV PRE INTELEKTOVO NADANYCH ZIAKOV. 2008. [online]. [cit. 2015-10-03]. Dostupne na internete: www2.statpedu.sk/buxus/docs/integracia /integrnadan2.pdf

MUlleT, D. - WILlERSON, A. - LAMB, K. - KETTLER, T. 2016. Examining teacher perceptions of creativity: A systematic review of the literature Thinking Skills and Creativity, 21, p. 9-30.

RUNCO, A. M. 2005. Creative Giftedness. In R. J. Sternberg \& J. E. Davidson (Eds.), Conceptions of giftedness (p. 295-311). New York: Cambridge University Press.

SIMONTON, D. 2012. Taking the U.S. Patent Office creativity criteria seriously: A quantitative threecriterion definition and its implications. Creativity Research Journal, 24, p. 97-106. 
SZOBIOVA, E. 2016. Tvorivost - poznavanie tajomstiev. Plzen: Ales Cenek, 2016. ISBN 978-80-7380-613-2. $386 \mathrm{~s}$.

SZOBIOVA, E. - BOLEKOVA, V. 2012. Sebaucta a tvorivost nadanych pubescentov. In A. Heretik, E. Rosková (Eds.); Psychologica 41, Zbornik Filozofickej fakulty Univerzity Komenskeho $\mathrm{v}$ Bratislave, Univerzita Komenskeho, Stimul, FiFUK, 2012, s. 897-910. ISBN 978-80-8127-057-4.

SZOBIOVA, E. - SUPLATOVA, L. 2006. Tvorivost a osobnostne vlastnosti nadanych deti. Psychologia a patopsychologia, 41(3), s. 195-208

WESTBY, E. - DAWSON, V. 2010. Creativity: Asset or Burden in the Classroom? Available online: http://www.tandfonline.com/doi/abs/10.1207/s15326934crj0801_1

ZENASNI, F. - MOURGUES, C. - NELSON, J. - MUTTER, C. MYSKOWSKI, N. 2016. How does creative giftedness differ from academic giftedness? A multidimensional conception. Learning and Individual Differences, 52, p. 216-223.

PhDr. PaedDr. Dušan Fábik

Pan-European university

Faculty of psychology

Tomášiková 20

Bratislava

Slovakia

dusan.fabik@centrum.sk 